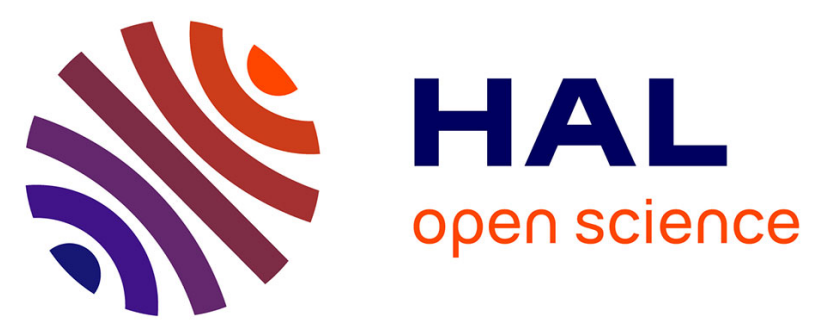

\title{
Effects of the addition of various minerals, proteins and salts of organic acids on the principal steps of $\alpha$-lactose monohydrate crystallisation
}

\author{
Gwénolé Gernigon, Fabien Baillon, Fabienne Espitalier, Cécile Le \\ Floch-Fouéré, Pierre Schuck, Romain Jeantet
}

\section{To cite this version:}

Gwénolé Gernigon, Fabien Baillon, Fabienne Espitalier, Cécile Le Floch-Fouéré, Pierre Schuck, et al.. Effects of the addition of various minerals, proteins and salts of organic acids on the principal steps of $\alpha$-lactose monohydrate crystallisation. International Dairy Journal, 2013, 30 (2), pp.88-95. 10.1016/j.idairyj.2012.12.005 . hal-01209403

\section{HAL Id: hal-01209403 \\ https://hal.science/hal-01209403}

Submitted on 5 Sep 2018

HAL is a multi-disciplinary open access archive for the deposit and dissemination of scientific research documents, whether they are published or not. The documents may come from teaching and research institutions in France or abroad, or from public or private research centers.
L'archive ouverte pluridisciplinaire HAL, est destinée au dépôt et à la diffusion de documents scientifiques de niveau recherche, publiés ou non, émanant des établissements d'enseignement et de recherche français ou étrangers, des laboratoires publics ou privés. 


\title{
Effects of the addition of various minerals, proteins and salts of organic acids on the principal steps of $\alpha$-lactose monohydrate crystallisation
}

\author{
Gwénolé Gernigon $^{\mathrm{a}, \mathrm{b}}$, Fabien Baillon ${ }^{\mathrm{c}}$, Fabienne Espitalier ${ }^{\mathrm{c}}$, Cécile Le Floch-Fouéré ${ }^{\mathrm{a}, \mathrm{b}}$, Pierre Schuck ${ }^{\mathrm{a}, \mathrm{b}, *}$, \\ Romain Jeantet $^{\mathrm{a}, \mathrm{b}}$ \\ a INRA, UMR1253, F-35000 Rennes, France \\ ${ }^{\mathrm{b}}$ Agrocampus Ouest, UMR1253, F-35000 Rennes, France \\ ' Université de Toulouse, Mines Albi-Carmaux, UMR CNRS 5302, F-81013 Albi, France
}

\begin{abstract}
A B S T R A C T
To study the effects of whey constituents on lactose crystallisation, a model based on population balance and taking into account mutarotation was implemented. Outputs were the nucleation constants $\left(B_{0}, k_{n 0}\right)$ and the growth rate constants $\left(\mathrm{kg}_{0}, \mathrm{~g}_{0}\right)$. Batch crystallisation of a lactose solution (70 g $100 \mathrm{~g}^{-1}$ water) was studied with and without addition of various organic acids, salts, galactose and proteins. Kinetics and crystal size distributions were monitored using refractometry and laser light scattering. Factorial analysis of the results highlighted that the presence of organic acids (lactate, citrate) leads to faster crystallisation and confirmed the fact that whey proteins are slowing down the crystal growth step. The results of this study make a contribution towards a better understanding of lactose crystallisation.
\end{abstract}

\section{Introduction}

The dairy industry has to process huge amounts of whey each year. For example, the European production of cheese in 2010 was 8.533 million tonnes (FIL-IDF, 2011), corresponding to roughly 77 million tonnes of liquid whey. Because of environmental and economic considerations, as well as potential benefits for health, whey is no longer considered a waste product (Smithers, 2008). It is therefore of the utmost importance to process whey properly to supply the ingredient market with high quality products. However, whey is not an easy product to process. In fact, it contains a great deal of free water, lactose, soluble proteins and varying amounts of minerals, especially calcium, phosphate and various monovalent ions. If lactose is not properly crystallised, whey cannot be spray dried correctly without a reduced flow rate and decreased functional properties of the powder. Unfortunately, whey composition is highly variable (De Wit, 2001; Gernigon, Piot, Beaucher, Jeantet, \& Schuck, 2009), which makes it difficult to anticipate in process optimisation for further processing.

Crystallisation of $\alpha$-lactose has been studied and reviewed by several authors, in particular Haase and Nickerson (1966), Hartel (2001), Hartel and Shastry (1991), Nickerson and Moore (1974),

\footnotetext{
* Corresponding author. Tel.: +3322 3485322.

E-mail address: pierre.schuck@rennes.inra.fr (P. Schuck).
}

Twieg and Nickerson (1968) and Visser (1980, 1982, 1984, 1988). More recently Mc Leod, Paterson, Jones, and Bronlund (2011) studied the nucleation mechanisms of $\alpha$-lactose and Wong, Bund, Connelly, and Hartel (2010) modelled the continuous crystallisation of $\alpha$-lactose through artificial neural networks.

Lactose crystallisation consists of a set of complex reactions that strongly depend on the experimental conditions used (temperature, agitation, supersaturation). The three fundamental steps in $\alpha$-lactose crystallisation in aqueous solutions are nucleation, crystal growth and mutarotation. These steps were often studied separately in the past, with certain simplifications with regard to the other steps (e.g., non rate-limiting mutarotation). Considerable improvement in the understanding of this phenomenon was achieved following the publication by Mimouni, Schuck, and Bouhallab (2009) of a kinetic model combining the different stages of lactose crystallisation. It was demonstrated that lactose crystallisation may depend on the mutarotation step, a fact that has been debated for many years. However, its high number of degrees of freedom limits this model, especially when there are few input measurements, as in the present study. It is therefore difficult to rely on the various constants whose value may vary according to the adjustment sequence chosen.

In our study we developed a new model based on crystallisation theory and on this model for mutarotation, first by applying population and material balances, and secondly by using model solutions to study crystallisation experimentally. 


\section{Materials and methods}

\subsection{Reagents and solutions}

\subsubsection{Reagents}

As part of an industrial study about mozzarella whey, the studied compounds were chosen to be representative of the composition of mozzarella whey as determined by Gernigon et al. (2009). Laboratory grade alpha-lactose monohydrate (VWR, Fontenay-sous-Bois, France) was used for the preparation of the supersaturated solution. Pharmaceutical lactose (Asmar, Meulan, France) was used for preparation of the dispersing solution for scattering.

Anhydrous calcium chloride, galactose and calcium lactate pentahydrate were provided by Sigma Aldrich (Lyon, France), and lactic acid (90\%), trisodium citrate tetrahydrate, hydrochloric acid (32\%), potassium chloride, sodium hydroxide and ammonia by VWR. The whey protein isolate (WPI) used was Prolacta ${ }^{\circledR}$ (Lactalis, Retiers, France). WPI was glycated (lactosylated or galactosylated) by a dry method for $48 \mathrm{~h}$ at $50{ }^{\circ} \mathrm{C}$ following the method of Morgan et al. (1999). Reverse osmosis water was used for the preparation of all solutions.

\subsubsection{Supersaturated solutions}

The solution of lactose was prepared in the $1 \mathrm{~L}$ unbaffled glass vessel ( $10 \mathrm{~cm}$ diameter) by dissolving $280 \mathrm{~g}$ anhydrous lactose in $400 \mathrm{~g}$ water at $70^{\circ} \mathrm{C}$, corresponding to a supersaturation ratio $(S)$ of 2.7 at $30^{\circ} \mathrm{C}\left(S=C \alpha / C \alpha_{\text {eq }}\right)$. This supersaturation ratio is sufficiently high to induce non-seeded crystallisation, but low enough to observe differences. The solution was heated on a steel plate until a clear solution was obtained. It was then cooled in a water bath at $30^{\circ} \mathrm{C}$ and held for $15 \mathrm{~min}$ without agitation and the constituent to be studied was added at the desired concentration below its solubility before beginning the experiment. Agitation was then commenced and time zero $\left(t_{0}\right)$ defined. The impeller was vertically and centrally mounted in the vessel. Agitation was provided by a marine-like impeller (diameter: $4.5 \mathrm{~cm}$ ) driven at $600 \pm 5 \mathrm{rpm}$ by a $16 \mathrm{~W}$ power electric motor (Eurostar digital, IKA-Werke, Staufen, Germany). This stirring rate permits the maintenance of crystals in suspension during the operation without vortex formation. The volume of the initial solution was $600 \mathrm{~mL}$. About $50 \mathrm{~mL}$ of suspension was sampled at the upper part of the vessel during the experiment for the refractometry and size distribution measurements; the final volume was thus about $550 \mathrm{~mL}$. Table 1 shows the composition, $\mathrm{pH}$ and the number of replicates of the different solutions studied. The solution of lactose without additives was chosen as the reference.

\subsection{Refractometry measurements: calibration curve}

Standard solutions were prepared, each with a constant additive concentration and increasing lactose concentration. For example, six standard solutions were prepared for lactic acid calibration. Each of these solutions contained $5 \mathrm{~g}$ lactic acid $100 \mathrm{~g}^{-1}$ water, but $20,30,40,60,70$ and $80 \mathrm{~g}$ lactose $100 \mathrm{~g}^{-1}$ water, respectively. The calibration consisted of placing these standard solutions in the same conditions as the experimental solution $\left(30^{\circ} \mathrm{C}\right)$ and measuring the refractive index ( ${ }^{\circ}$ Brix) for each of them. A Pal- $\alpha$ digital refractometer $\left(0-85^{\circ}\right.$ Brix; Atago, Tokyo, Japan) was used for all the refractometry measurements. Assuming there was no precipitation of additive during crystallisation, and knowing the lactose concentrations of the standard solutions, an hyperbolic curve was obtained, as in previous work by Mimouni, Schuck, and Bouhallab (2005), which permitted conversion of the refractometry results to concentrations (g $100 \mathrm{~g}^{-1}$ water). For example, for lactic acid calibration, the R-square of the fit was 0.99 and the equation obtained was:
Table 1

Description of the solutions. ${ }^{a}$

\begin{tabular}{|c|c|c|c|c|}
\hline Solution & $\begin{array}{l}\text { Initial } \\
\mathrm{pH}^{\mathrm{b}}\end{array}$ & $\begin{array}{l}\text { Final } \\
\mathrm{pH}^{\mathrm{b}}\end{array}$ & Additives $^{c}$ & $\begin{array}{l}\mathrm{n} \\
\text { replicates }\end{array}$ \\
\hline 0 & 3.40 & n.d. & - & 5 \\
\hline 1 & 5.80 & 6.70 & Sodium hydroxide (1.0) & 3 \\
\hline 2 & 3.50 & n.d. & Galactose (9.0) & 4 \\
\hline 3 & 5.74 & 6.94 & $\begin{array}{l}\text { Galactose }(9.0)+\text { sodium } \\
\text { hydroxide }(0.01)\end{array}$ & 1 \\
\hline 4 & 2.37 & 2.73 & Hydrocholoric acid (0.04) & 2 \\
\hline 5 & 2.10 & n.d. & Lactic acid (5.0) & 3 \\
\hline 6 & 2.67 & 2.58 & Lactic acid (0.5) & 2 \\
\hline 7 & 4.10 & n.d. & $\begin{array}{l}\text { Lactic acid }(1.0)+\text { calcium } \\
\text { lactate }(5.0)\end{array}$ & 3 \\
\hline 8 & 6.41 & 6.45 & $\begin{array}{l}\text { Lactic acid }(1.0)+\text { calcium } \\
\text { lactate }(5.0)+\text { sodium } \\
\text { hydroxide }(1.0)\end{array}$ & 2 \\
\hline 9 & 5.24 & 5.39 & $\begin{array}{l}\text { Calcium lactate }(1.0)+\text { sodium } \\
\text { hydroxide }(0.1)\end{array}$ & 2 \\
\hline 10 & 5.48 & n.d. & $\begin{array}{l}\text { Lactic acid }(6.0)+\text { sodium } \\
\text { hydroxide }(6.0)\end{array}$ & 3 \\
\hline 11 & 5.01 & 5.07 & $\begin{array}{l}\text { Lactic acid }(1.0)+\text { sodium } \\
\text { hydroxide }(0.6)\end{array}$ & 1 \\
\hline 12 & 7.56 & 7.53 & Sodium citrate (13.0) & 6 \\
\hline 13 & 7.19 & 7.16 & Sodium citrate (1.0) & 1 \\
\hline 14 & 4.50 & 5.12 & Calcium chloride (3.0) & 3 \\
\hline 15 & 5.82 & 6.29 & $\begin{array}{l}\text { Calcium chloride }(3.0)+\text { sodium } \\
\text { hydroxide }(0.01)\end{array}$ & 2 \\
\hline 16 & 3.49 & 4.07 & Potassium chloride (2.0) & 3 \\
\hline 17 & n.d. & n.d. & Ammonia (1.0) & 3 \\
\hline 18 & 6.50 & 6.49 & Whey protein isolate (5.0) & 1 \\
\hline 19 & 6.50 & 6.49 & $\begin{array}{l}\text { Whey protein isolate }(5.0) \\
+ \text { galactose }(9.0)\end{array}$ & 1 \\
\hline 20 & n.d. & n.d. & $\begin{array}{l}\text { Galactosylated whey protein } \\
\text { isolate (5.0) }\end{array}$ & 1 \\
\hline 21 & 6.10 & 5.93 & $\begin{array}{l}\text { Lactosylated whey protein } \\
\text { isolate (5.0) }\end{array}$ & 1 \\
\hline
\end{tabular}

\footnotetext{
${ }^{\text {a }}$ All solutions made using $70 \mathrm{~g}$ lactose $100 \mathrm{~g}^{-1}$ water.

b n.d., not determined.

${ }^{c}$ Concentrations given in parentheses (g $100 \mathrm{~g}^{-1}$ water).
}

$$
\begin{aligned}
& \text { Concentration (g } \left.100 \mathrm{~g}^{-1} \text { water }\right) \\
& =-24+23 /\left(1+3.98 .10^{-3 *} \text { Brix }\right)^{(-1 / 0.1)}
\end{aligned}
$$

\subsection{Particle size distribution measurements}

The particle size distribution of $\alpha$-lactose monohydrate crystals resulting from the crystallisation process was determined by laser light scattering at ambient temperature using a MasterSizer 2000 (Malvern Instruments, Malvern, UK) equipped with a $5 \mathrm{~mW} \mathrm{He}-\mathrm{Ne}$ laser operating at a wavelength of $633 \mathrm{~nm}$. A slightly supersatu-

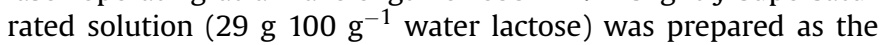
dispersing medium for laser light scattering, to avoid dissolution of lactose crystals in the measurement cell (Mimouni et al., 2005). The slurry collected from the crystallisation experiment was added directly into $100 \mathrm{~mL}$ of the slightly supersaturated lactose solution in the measurement cell of the apparatus to reach $8 \%$ obscuration. The refractive indices used for solvent and particles were 1.37 and 1.53 , respectively. From the size distribution, different particle diameters were calculated: the mean volume diameter $d(4,3)$ and the mean-surface diameter $d(3,2)$.

\subsection{Model}

\subsubsection{Population balance}

For a closed system with a constant volume $\mathrm{V}$, the population balance necessary to describe the transient particle size distribution in a constant volume, isothermal and well mixed crystalliser 
without agglomeration and breakage is presented in Eq. (1) (Mersmann, 1995).

$\frac{\partial}{\partial t}(n(L))=j \delta\left(L-L_{C}\right)-\frac{d}{d L}(G n(L))$

where $n(L)$ is the population density of lactose crystals $\left(\# \mathrm{~m}^{-1} \mathrm{~m}^{-3}\right)$, $L$ the particle size $(\mathrm{m}), J$ the nucleation rate $\left(\# \mathrm{~m}^{-3} \mathrm{~s}^{-1}\right), G$ the crystal growth rate $\left(\mathrm{m} \mathrm{s}^{-1}\right), L_{C}$ the nucleus size $(\mathrm{m}) . \delta$ is the Dirac function, and has the following characteristic values:

if $L=L_{C}$ then $\delta\left(L-L_{C}\right)=1$

if $L \neq L_{c}$ then $\delta\left(L-L_{C}\right)=0$

Thus, the population balance takes into account the different phenomena involved (nucleation, crystal growth) in the course of crystallisation.

This general formula has to be revised to take into account the moments to have access to the experimental values by assuming a growth rate independent of size. Expression of the moment of $j$ order $\mu_{j}$ is provided in Eq. (2):

$\mu_{j}=\int_{0}^{\infty} n L^{j} d L$

Equation (3) provides expression of the population balance depending on the moments for a constant suspension volume (Mersmann, 1995):

$\frac{\partial}{\partial t}\left(\mu_{j}\right)=0^{j} \cdot J+j \cdot G \cdot\left(\mu_{j-1}\right)$

On the basis of the population balance provided by Eq. (3), we can establish the differential equations transformed in terms of moments of order zero to four. Assuming that there is no agglomeration or breaking, the population balance in the closed vessel can be expressed by the differential equations of nucleation (Eq. (4), $j=0$ ) and growth (Eq. (5); $0<j<4$ ):

$\frac{\partial}{\partial t}\left(\mu_{0}\right)=J$

$\frac{\partial}{\partial t}\left(\mu_{j}\right)=j G \mu_{j-1}$

The mean volume diameter $(\mu \mathrm{m})$ is calculated from the moments of order 3 and 4 :

$d(4,3)=\frac{\mu_{4}}{\mu_{3}}$

\subsubsection{Material balances}

The change in solute concentration is calculated from the mass balance on the lactose, expressed by:

Accumulation + rates of mutarotation reaction

+ transfer rate between phases

$=0$

The reactions involved for $\alpha$-lactose in solution are the mutarotation reactions and the transfer between phases corresponding to crystallisation:

$$
\begin{aligned}
\frac{d C_{\alpha}}{d t}= & \frac{1}{m_{\text {water }}}\left[C_{\alpha}\left(1-\frac{1}{R_{L}}\right)-\frac{1}{R_{L}}\right] \phi_{v} \rho_{\text {lactose }} V \frac{d \mu_{3}}{d t}-k_{1} \cdot C_{\alpha} \\
& +k_{2} \cdot C_{\beta}
\end{aligned}
$$

where $R_{L}$ is the ratio between the molar masses of respectively hydrated lactose and anhydrous lactose, $C_{\alpha}$ and $C_{\beta}$ the concentrations in $\alpha$ - and $\beta$-lactose respectively (g $100 \mathrm{~g}^{-1}$ water), $m_{\text {water }}$ the water mass $(\mathrm{g}), \phi_{v}$ the volume shape factor $(-)$, $\phi_{\text {lactose }}$ the olumic mass of lactose $\left(\mathrm{g} \mathrm{m}^{-3}\right), V$ the volume of solution $\left(\mathrm{m}^{3}\right), C \alpha_{\text {eq }}$ the $\alpha$ lactose concentration at equilibrium ( $100 \mathrm{~g}^{-1}$ water) and $k_{1}$ and $k_{2}$ the mutarotation constants $\left(\mathrm{s}^{-1}\right)$

$\frac{d C_{\beta}}{d t}=k_{1} \cdot C_{\alpha}-k_{2} \cdot C_{\beta}+\frac{C_{\beta}\left(1-\frac{1}{R_{L}}\right)}{m_{\text {water }}} \phi_{v} \rho_{\text {lactose }} V \frac{d \mu_{3}}{d t}$

The change in mass of water (hydrated lactose crystal) is expressed by:

$\frac{d m_{\text {water }}}{d t}=-\left(1-\frac{1}{R_{L}}\right) \phi_{v} \rho_{\text {lactose }} V \frac{d \mu_{3}}{d t}$

The total lactose concentration in the solution is expressed by

$C=C_{\alpha}+C_{\beta}$

where $C$ is the total lactose concentration (g. $100 \mathrm{~g}^{-1}$ water) which can be measured.

\subsubsection{Expression of the kinetic constants}

In addition, we chose classical laws to express homogeneous primary nucleation kinetic (Eqs (11) and (12)) and growth rate kinetics (Eq. (13))

$J=k_{n 0} \cdot \exp \frac{-B_{0}}{\left(\ln \left(\frac{C_{\alpha}}{C_{\alpha, \text { eq }}}\right)\right)^{2}}$

with

$B_{0}=\frac{\phi_{v} \cdot V_{m}^{2} \cdot \gamma^{3}}{(k \cdot T)^{3}}$

where $V_{m}$ is the molecular volume of lactose $\left(\mathrm{m}^{3}\right), \gamma$ the surface energy crystal/solution $\left(\mathrm{J} \mathrm{m}^{-2}\right), \quad k$ the Boltzmann constant $\left(1.38 \times 10^{-23} \mathrm{~J} \mathrm{~K}^{-1}\right), T$ the temperature $(\mathrm{K}), B_{0}$ the nucleation constant (-) and $k_{n 0}$ the nucleation rate constant (nuclei $\mathrm{m}^{-3} \mathrm{~s}^{-1}$ ). The last two parameters are identified.

We assume lactose solubility as constant in the model, as the final concentrations of our experiments were quite similar. However further studies are required to check this assumption as Smart (1988) had shown that some effect on solubility were possible. At $30{ }^{\circ} \mathrm{C}$, an $\alpha$-lactose solubility of $11.28 \mathrm{~g} 100 \mathrm{~g}^{-1}$ water was used in the model (Mimouni et al., 2009).

$G=k_{g 0}\left(C_{\alpha}-C_{\alpha, \mathrm{eq}}\right)^{g 0}$

where $k_{g 0}$ is the growth rate constant $\left(\mathrm{m} \mathrm{s}^{-1}\right)$ and $g_{0}$ the growth rate order $(-)$. The last two parameters are identified.

\subsection{Results of fitted parameters}

The four parameters, $k_{n 0}, B_{0}, k_{g 0}$ and $g_{0}$, were estimated from the experimental data (concentration and mean volume diameter) by minimisation of a scalar function. The functions fminsearch and 

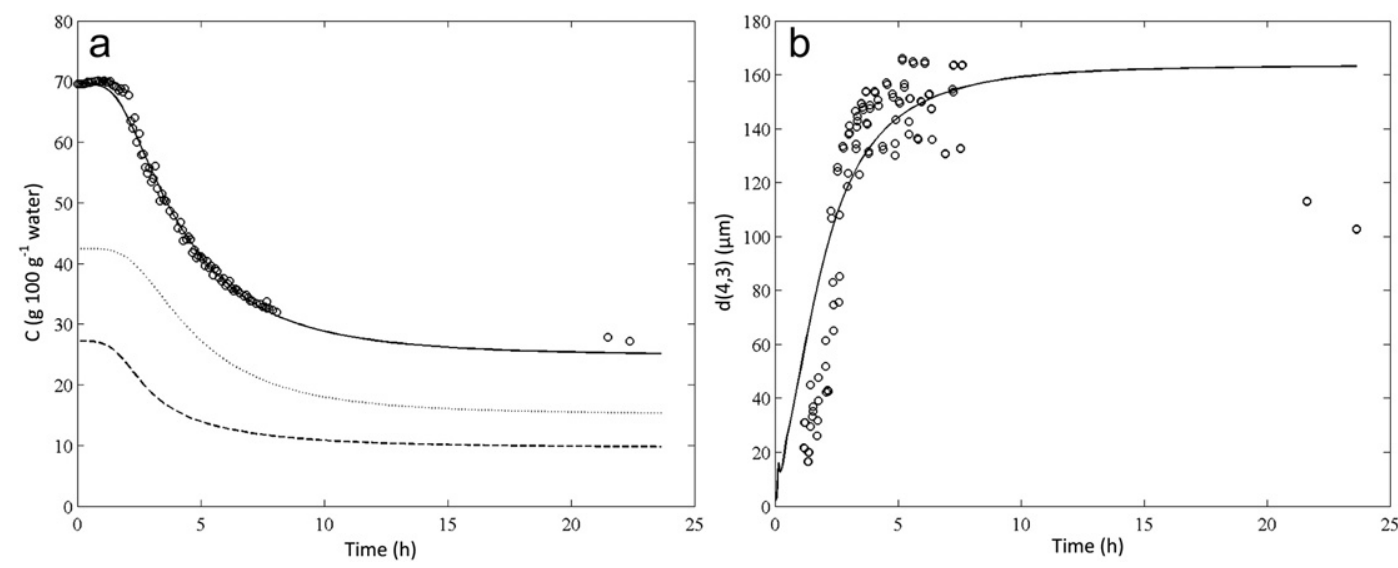

Fig. 1. Fit of the model on solution 0 (reference) regarding (a) the concentration ( $\left(100 \mathrm{~g}^{-1}\right.$ water; $\mathrm{MSD}=2.47 \times 10^{-3}$ ) and $(\mathrm{b})$ the mean volume diameter $\left(\mu \mathrm{m}\right.$; MSD $=3.76 \times 10^{-2}$ ): $\bigcirc$, experimental data; - , calculated values for total concentration and mean volume diameter; $\cdots$, concentration of $\beta$-lactose (g $100 \mathrm{~g}-1$ water); - - -, concentration of $\alpha$-lactose (g $100 \mathrm{~g}^{-1}$ water).

ode45 of MATLAB ${ }^{\circledR}$ software (2011a, The MathWorks, Natick, MA, USA) were used respectively to find the minimum of a scalar function depending of $k_{n 0}, B_{0}, k_{g 0}$ and $g_{0}$ variables, and to solve the systems of eight differential Eqs. (4)-(8). The scalar function minimised was:

$f=\sum_{j=1}^{\text {npoints }}\left(\frac{\left(C_{j, \text { cal }}-C_{j, \exp }\right)^{2}}{\left(C_{j, \exp }\right)^{2}}\right)+\frac{\left(d_{\text {cal }}(4,3)-d_{\exp }(4,3)\right)^{2}}{\left(d_{\exp }(4,3)\right)^{2}}$

All points of lactose concentrations are chosen to define this function and only one point is used for the mean volume diameter. The mean volume diameter observed on the final plateau was taken (Fig. 1).

The quality of the fit was assessed through the mean standard deviation (MSD), on the concentration and mean volume diameter $d(4,3)$ values. Results of the model and quality of the fit are reported in Table 2.

Fig. 1 shows the experimental data (total concentration of lactose (a) and mean volume diameter (a)) and the predicted results for the reference. We can observe a good agreement between experimental data and predicted results. Fig. 2 presents the experimental data and the predicted results for the reference for the solution having the worse fit on concentration (MSD $=26.44$ ). This result is due to the high dispersion of experimental points between two independent experiments. Despite this, an adequate agreement it is observed for all experiments treated. The output variables of the system are $J$ and $G$, corresponding to the kinetics of nucleation and crystal growth, respectively, and linked to the fitted parameters (kinetics constants $k^{n}$ and $B_{0}$ for nucleation, and $k_{g}$ and $g_{0}$ for crystal growth). $J$ and $G$ decline during the crystallisation process, as a result of crystal formation, and therefore the initial values of these rates $\left(J_{i}\right.$ and $\left.G_{i}\right)$ were retained as variables for analysis of the results. Moreover, two interesting parameters were

Table 2

Fitted parameter values $\left[k_{n 0}\left(\right.\right.$ nuclei $\left.\mathrm{m}^{-3} \mathrm{~s}^{-1}\right), B_{0}(-), k_{\mathrm{g} 0}\left(\mathrm{~m} \mathrm{~s}^{-1}\right)$ and $\left.g_{0}(-)\right]$, interface tension crystal/solution $\gamma\left(\mathrm{J} \mathrm{m}^{-2}\right), \beta / \alpha$ ratio and kinetic rate values $\left[J_{i}\left(\right.\right.$ nuclei $\left.\mathrm{m}^{-3} \mathrm{~s}^{-1}\right)$ and $G_{i}$ $\left.\left(\mathrm{m} \mathrm{s}^{-1}\right)\right]$ as well as the quality of the fit by the model, using mean standard deviation (MSD).

\begin{tabular}{|c|c|c|c|c|c|c|c|c|c|c|c|c|}
\hline Solution & $\begin{array}{l}k_{n 0} \\
\left(\times 10^{-8}\right)\end{array}$ & $B_{0}$ & $\begin{array}{l}k_{g 0} \\
\left(\mathrm{~m} \mathrm{~s}^{-1}\right) \\
\left(\times 10^{7}\right)\end{array}$ & $g_{0}$ & $\begin{array}{l}\gamma \\
\left(\mathrm{J} \mathrm{m}^{-2}\right) \\
\left(\times 10^{3}\right)\end{array}$ & $\beta / \alpha$ & $\begin{array}{l}J_{i} \\
\left(\# \mathrm{~m}^{-3} \mathrm{~s}^{-1}\right) \\
\left(\times 10^{-7}\right)\end{array}$ & $\begin{array}{l}G_{i} \\
\left(\mathrm{~m} \mathrm{~s}^{-1}\right) \\
\left(\times 10^{8}\right)\end{array}$ & $\begin{array}{l}\text { MSD on } \\
\text { concentration } \\
\mathrm{C}\left(\times 10^{3}\right)\end{array}$ & $\begin{array}{l}\text { Number } \\
\text { of points } \\
\text { (Concentration) }\end{array}$ & $\begin{array}{l}\text { MSD on } \\
\text { diameter d43 } \\
\left(\times 10^{2}\right)\end{array}$ & $\begin{array}{l}\text { Number } \\
\text { of points } \\
\text { (diameter }\end{array}$ \\
\hline 0 & 7.86 & 4.90 & 2.06 & 1.48 & 5.22 & 2.02 & 1.95 & 1.71 & 2.47 & 91 & 3.76 & 109 \\
\hline 1 & 1.65 & 2.84 & 1.59 & 1.29 & 4.35 & 2.13 & 2.02 & 1.86 & 7.98 & 61 & 3.11 & 69 \\
\hline 2 & 4.31 & 3.72 & 2.89 & 1.64 & 4.76 & 2.02 & 2.59 & 1.82 & 3.11 & 107 & 3.79 & 130 \\
\hline 3 & 5.27 & 3.99 & 2.17 & 1.43 & 4.88 & 2.11 & 2.63 & 1.99 & 3.51 & 26 & 5.25 & 36 \\
\hline 4 & 3.54 & 4.66 & 1.42 & 1.30 & 5.13 & 2.01 & 1.10 & 1.62 & 7.53 & 90 & 2.74 & 48 \\
\hline 5 & 1.06 & 5.84 & 1.18 & 1.01 & 5.53 & 2.27 & 1.39 & 2.21 & 2.26 & 105 & 4.09 & 87 \\
\hline 6 & 2.91 & 3.70 & 2.09 & 1.36 & 4.75 & 2.13 & 1.83 & 2.15 & 3.36 & 50 & 3.25 & 68 \\
\hline 7 & 7.29 & 2.92 & 2.10 & 1.17 & 4.40 & 2.56 & 8.11 & 2.93 & 6.02 & 53 & 1.06 & 73 \\
\hline 8 & 6.09 & 3.26 & 3.29 & 1.32 & 4.56 & 2.49 & 5.37 & 3.61 & 2.63 & 67 & 1.43 & 63 \\
\hline 9 & 3.43 & 2.41 & 3.02 & 1.61 & 4.12 & 2.15 & 5.68 & 2.06 & 1.67 & 58 & 3.72 & 63 \\
\hline 10 & 5.87 & 2.81 & 1.89 & 1.21 & 4.34 & 2.43 & 7.02 & 2.47 & 3.45 & 70 & 1.44 & 64 \\
\hline 11 & 7.06 & 4.01 & 2.34 & 1.52 & 4.88 & 2.08 & 3.48 & 1.82 & 2.25 & 41 & 4.23 & 32 \\
\hline 12 & 6.49 & 3.50 & 1.32 & 0.84 & 4.67 & 2.90 & 4.79 & 3.22 & 4.48 & 108 & 2.04 & 148 \\
\hline 13 & 9.63 & 3.62 & 1.18 & 0.97 & 4.72 & 2.57 & 6.41 & 2.33 & 3.45 & 17 & 2.34 & 24 \\
\hline 14 & 19.0 & 4.97 & 6.01 & 1.81 & 5.25 & 2.15 & 4.63 & 2.88 & 3.68 & 68 & 0.87 & 102 \\
\hline 15 & 17.6 & 6.16 & 3.17 & 1.49 & 5.63 & 2.15 & 1.92 & 2.68 & 2.13 & 47 & 1.66 & 63 \\
\hline 16 & 1.36 & 1.77 & 9.17 & 2.06 & 3.72 & 2.07 & 3.62 & 2.90 & 6.56 & 88 & 2.74 & 71 \\
\hline 17 & 20.5 & 5.18 & 0.68 & 1.06 & 5.32 & 2.14 & 4.32 & 1.16 & 26.4 & 45 & 4.26 & 61 \\
\hline 18 & 4.80 & 2.49 & 2.27 & 1.69 & 4.17 & 2.03 & 7.48 & 1.34 & 3.57 & 23 & 3.85 & 32 \\
\hline 19 & 7.08 & 3.29 & 7.69 & 2.29 & 4.57 & 1.93 & 5.87 & 1.64 & 18.2 & 23 & 8.80 & 31 \\
\hline 20 & 6.80 & 2.41 & 2.73 & 1.93 & 4.12 & 1.85 & 7.65 & 0.82 & 9.29 & 13 & 5.31 & 18 \\
\hline 21 & 1.82 & 1.89 & 1.77 & 1.50 & 3.80 & 2.01 & 4.02 & 1.32 & 10.5 & 20 & 3.76 & 32 \\
\hline
\end{tabular}



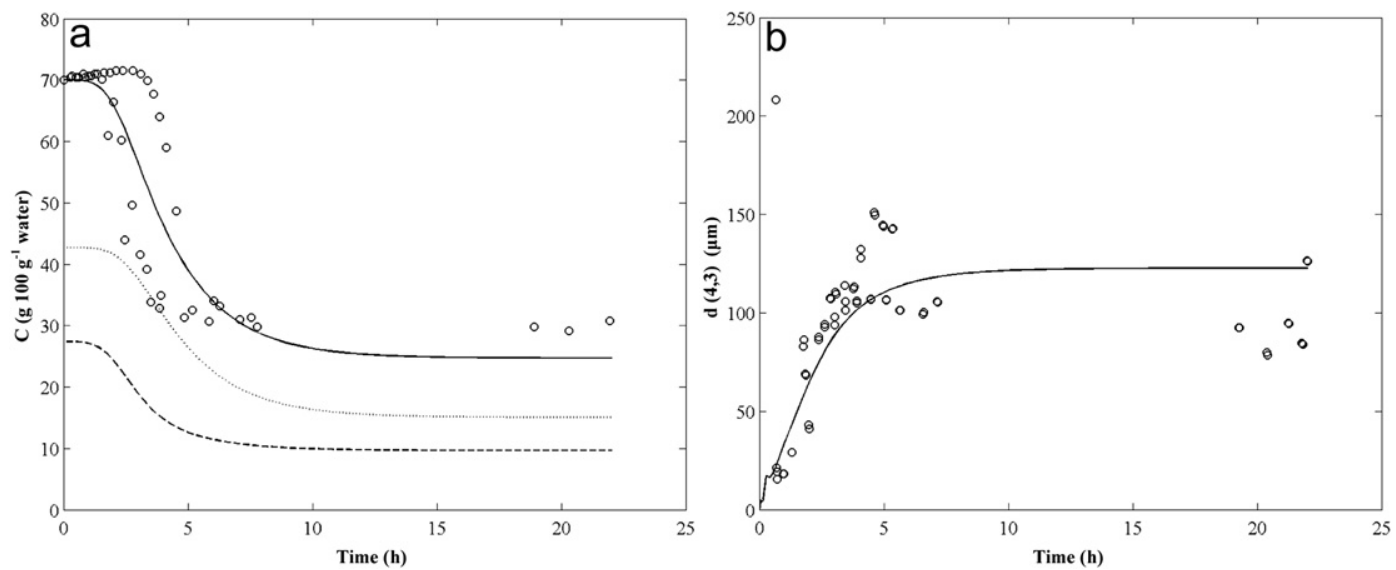

Fig. 2. Fit of the model on solution 17 (worst fit) regarding the concentration (a) $\left(\mathrm{MSD}=2.6410^{-2}\right)$ and the diameter $(\mathrm{b})\left(\mathrm{MSD}=4.26 \times 10^{-2}\right)$ : $\bigcirc$, experimental data; - , calculated values for total concentration and mean volume diameter; $\cdots$, concentration of $\beta$-lactose ( $100 \mathrm{~g}^{-1}$ water), - - , concentration of $\alpha$-lactose ( $\mathrm{g} 100 \mathrm{~g}{ }^{-1}$ water).

retained, i.e., the surface energy between crystal and solution, deduced from the $B_{0}$, and the maximum $\beta$-lactose/ $\alpha$-lactose ratio, corresponding to the maximum consumption of $\alpha$-lactose.

\subsection{Statistical analyses}

The complete data set was analysed using principal components analysis (PCA). The general principles of this multivariate statistical technique have been described in detail elsewhere (Jollife, 2002). PCA was applied to the whole set of 22 crystallisation experiments, after centreing (average subtraction) and scaling. The reference was placed as illustrative individual, i.e., not taking part in the construction of the factorial map. The active variables of the PCA were $B_{0}, k_{n 0}, \gamma, J_{i}, k_{g 0}, g_{0}, G_{i}$ and $\beta / \alpha$. Hierarchical clustering on principal components (HCPC) was performed, to highlight similarities between groups of individuals (Husson, Josse, \& Pagès, 2010) using Ward's algorithm, which consists of aggregating two clusters such

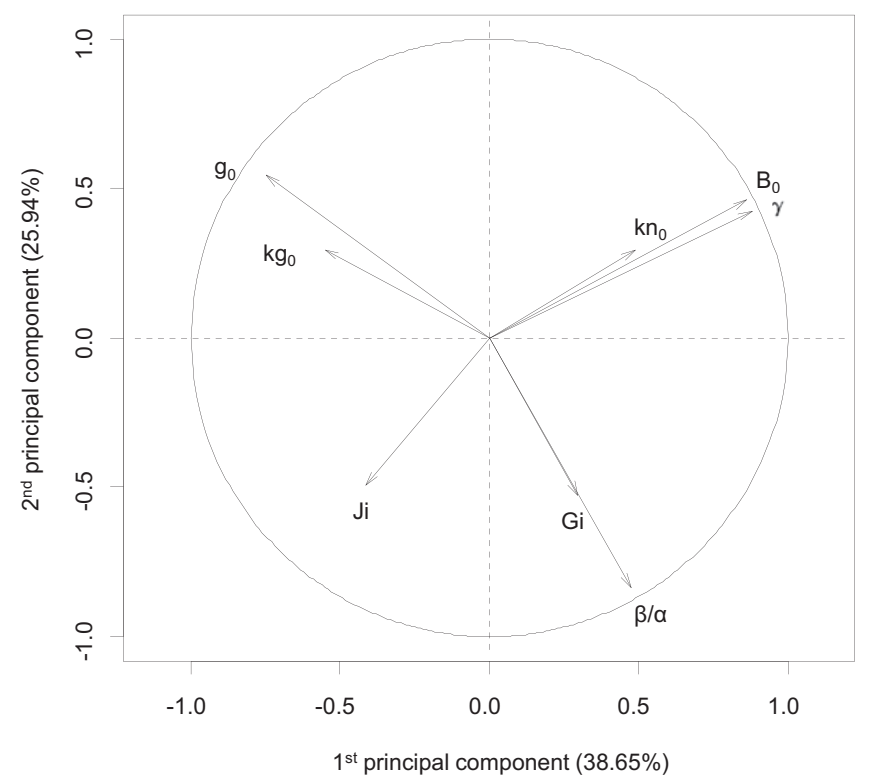

Fig. 3. Correlation circle of the principal components analysis (PCA) performed on the crystallisation experiments (Table 1). The correlations between the variables are shown by the angle between their projections in the circle. High correlations will result in alignment of the vectors. The quality of the projection is shown by the proximity of the vector to the circle. that the growth of within-inertia is minimum at each step of the algorithm. The within inertia characterises the homogeneity of a cluster. The hierarchical clustering is performed onto the principal components. Similarly the paragons of each cluster were calculated. Main paragons are individuals closest to the centre of a class, regarding all their coordinates in the variable space. Statistical analyses were performed using the Rcmdr package version 1.60 (Fox, 2005) of R software version 2.11.1 (R Development Core Team, 2010). PCA and HCPC were done using the FactoMineR package, version 1.14 (Husson, Josse, Le, \& Mazet, 2010). Differences between the clusters standardised values for each parameter were checked by analysis of variance (ANOVA) at a threshold of 0.05 performed using the Rcmdr package.

\section{Results and discussion}

\subsection{General considerations about the factorial map}

The factorial map (Fig. 3 for projection of variables and Fig. 4 for projection of individuals) summarises about $65 \%$ of the total inertia, which is satisfactory considering the number of active individuals (21) and variables (8). It means that the loss of initial information is only $35 \%$ while projecting a 21 dimension space (variables) or an 8 dimension space (individuals) on the 2 dimensions of the factorial map. The other significant components (component 3: 18\% inertia and component $4: 13 \%$ inertia) were also analysed but did not add sufficient information.

\subsection{Factor interpretation (based on the correlation circle and the correlation matrix)}

Fig. 3 displays the correlation circle (projection of the variables on the factorial map). The correlations between the variables are shown by the angle between their projections in the circle. High correlations will result in alignment of the vectors. The quality of the projection is shown by the proximity of the vector to the circle. The first principal component is correlated with $B_{0}$ and $\gamma(86 \%$ and $88 \%$, respectively). It can thus be considered that this axis displays individuals according to their behaviour regarding nucleation. However $g_{0}$, which is the order of the growth reaction, is also correlated with this axis $(-75 \%)$, showing the complexity of crystallisation, which is composed of two interdependent stages. The second principal component is correlated with the maximum $\beta / \alpha$ ratio $(-83 \%)$, which can be viewed as a mutarotation imbalance induced 


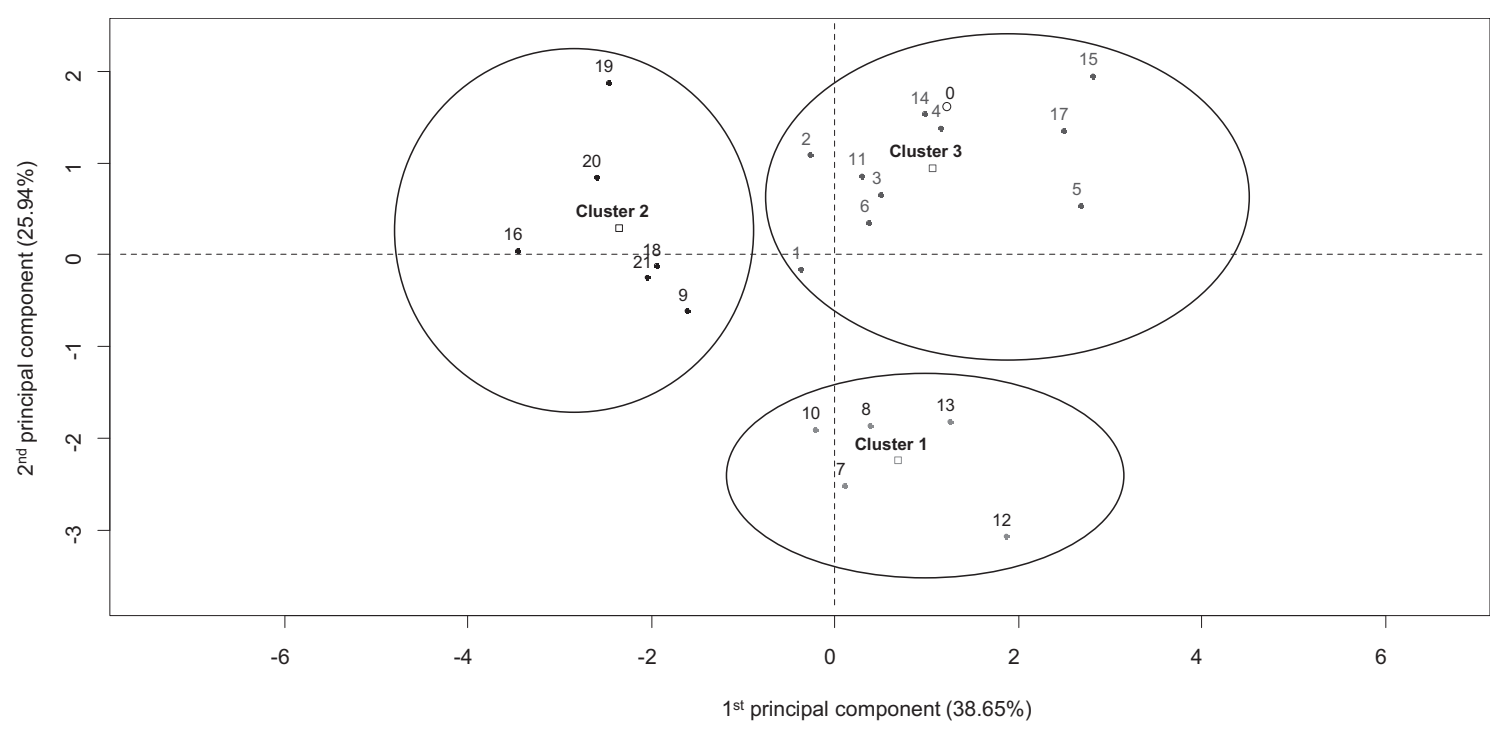

Fig. 4. Individual graph with hierarchical clustering on principal components. The individuals are projected in the factorial map following their similarities and the geometrical centres of the clusters are also projected. The designation of the individuals corresponds to the designation of the solutions in Table 1.

by the consumption of $\alpha$-lactose during crystallisation, and thus as the limit of the mutarotation reaction. To summarise, the first principal component tends to scatter individuals through their behaviour in nucleation (which is correlated with the crystal/solution interface tension) and the second principal component through their $\alpha$-lactose consumption (which is correlated with the kinetics). To have a complete vision of the correlations between the variables, it is important to comment on the correlation matrix (Table 3). The most significant correlation link $B_{0}$ and $\gamma$, which is easily explained by Eq. (12), and $k_{g 0}$ and $g_{0}$, the pair of growth constants (Eq. (13)). It should also be noted that $G_{i}$ is almost twice as highly correlated to the maximum $\beta / \alpha$ ratio than $J_{i}$, which is a confirmation that crystal growth consumes more $\alpha$-lactose than nucleation.

\subsection{Analysis of the clusters originating from the hierarchical clustering on principal components}

Fig. 4 displays the projection of individuals on the factorial map following their similarities with the geometrical centres of the clusters formed by HCPC also projected. Table 4 details the differences between the three clusters, showing their standardised mean values for the different kinetics. The standardised values of the first three paragons of each cluster are given to discuss the composition of the clusters (Table 4); paragons are the solutions that are closest to the centre of a cluster, and thus those which are the most

Table 3

Linear correlations between variables of interest. ${ }^{a}$

\begin{tabular}{lllrrrrr}
\hline Variable & $B_{0}$ & \multicolumn{1}{l}{$J_{i}$} & \multicolumn{1}{c}{$\gamma$} & \multicolumn{1}{c}{$k_{g 0}$} & \multicolumn{1}{c}{$g_{0}$} & \multicolumn{1}{c}{$G_{i}$} & \multicolumn{1}{c}{$\beta / \alpha$} \\
\hline$k_{n 0}$ & 0.62 & -0.08 & 0.56 & 0.16 & 0.17 & -0.04 & -0.09 \\
$B_{0}$ & & -0.63 & 0.98 & 0.17 & 0.03 & -0.10 & -0.13 \\
$J_{i}$ & & & -0.68 & -0.13 & -0.07 & 0.34 & 0.36 \\
$\gamma$ & & & & 0.15 & 0.00 & -0.08 & -0.10 \\
$k_{g 0}$ & & & & & 0.89 & -0.02 & -0.44 \\
$g_{0}$ & & & & & & -0.16 & -0.69 \\
$G_{i}$ & & & & & & & 0.60 \\
$\beta / \alpha$ & & & & & & &
\end{tabular}

a Variables: $k_{n 0}$ (nuclei $\mathrm{m}^{-3} \mathrm{~s}^{-1}$ ) and $B_{0}(-)$ are the nucleation constants; $J_{i}$ (nuclei $\left.\mathrm{m}^{-3} \mathrm{~s}^{-1}\right)$ is the nucleation rate; $k_{g 0}\left(\mathrm{~m} \mathrm{~s}^{-1}\right)$ and $g_{0}(-)$ are the constants related to crystal growth; $G_{i}\left(\mathrm{~m} \mathrm{~s}^{-1}\right)$ is the crystal growth rate; $\gamma$ is the interface tension crystal/solution $\left(\mathrm{J} \mathrm{m}^{-2}\right) ; \beta / \alpha(-)$ is the maximal ratio between $\beta$-lactose and $\alpha$-lactose. representative of the cluster. In addition, the experimental kinetics and scattering results of the blank (lactose $\mathrm{pH} 3$ ) are compared to those of the first paragon of each cluster (Fig. 5).

\subsubsection{Cluster 1}

Cluster 1 is clearly different from the other two clusters. It presents a highly negative score for factor 2 and a score close to zero for factor 1 (Fig. 4). Considering its high mean standardised values for $J_{i}$ and $G_{i}$, it can be clearly interpreted as a "fast crystallisation" cluster both for nucleation and crystal growth, respectively. These fast crystallisation kinetics led to the formation of many small sized crystals, as shown by the standardised values of this cluster (especially those of the paragons), complemented by the crystal growth curve (Fig. 5). The main paragon of cluster 1 (solution 7) had a shorter induction time than the blank, as shown in the left graph of Fig. 5. It resulted in the formation of smaller crystals, as shown in the right graph of Fig. 5. However, the crystal growth rate of solution 7 was higher than that of the blank. Smart (1988) made a study in a similar fashion of the effects of various additives commonly found in whey on lactose crystallisation. It was

Table 4

Description of the clusters by their mean and their 3 first paragons, i.e., the 3 individuals closest to the centre of each cluster. ${ }^{a}$

\begin{tabular}{|c|c|c|c|c|}
\hline & $\begin{array}{l}\text { Standardised } \\
J_{i}\end{array}$ & $\begin{array}{l}\text { Standardised } \\
\gamma\end{array}$ & $\begin{array}{l}\text { Standardised } \\
G_{i}\end{array}$ & $\begin{array}{l}\text { Standardised } \\
\beta / \alpha\end{array}$ \\
\hline Blank & -1.05 & 1.03 & -0.58 & -0.70 \\
\hline Cluster 1 mean & $0.94^{\mathrm{a}}$ & $-0.27^{\mathrm{a}}$ & $1.13^{\mathrm{a}}$ & $1.59^{\mathrm{a}}$ \\
\hline Solution 7 & 1.75 & -0.53 & 1.15 & 1.46 \\
\hline Solution 10 & 1.25 & -0.65 & 0.50 & 0.97 \\
\hline Solution 13 & 0.97 & 0.08 & 0.30 & 1.53 \\
\hline Cluster 2 mean & $0.66^{\mathrm{a}}$ & $-1.12^{\mathrm{b}}$ & $-0.61^{b}$ & $-0.73^{\mathrm{b}}$ \\
\hline Solution 9 & 0.64 & -1.05 & -0.08 & -0.16 \\
\hline Solution 18 & 1.46 & -0.96 & -1.10 & -0.66 \\
\hline Solution 20 & 1.54 & -1.05 & -1.82 & -1.35 \\
\hline Cluster 3 mean & $-0.79^{\mathrm{b}}$ & $0.73^{c}$ & $-0.18^{\mathrm{b}}$ & $-0.32^{\mathrm{b}}$ \\
\hline Solution 3 & -0.74 & 0.38 & -0.18 & -0.31 \\
\hline Solution 11 & -0.36 & 0.39 & -0.42 & -0.43 \\
\hline Solution 6 & -1.11 & 0.15 & 0.05 & -0.26 \\
\hline
\end{tabular}

a The superscript letters shows the results of the ANOVA between the clusters $(p=0.05) . J_{i}$ (nuclei $\left.\mathrm{m}^{-3} \mathrm{~s}^{-1}\right)$ is the nucleation rate, $G_{i}\left(\mathrm{~m} \mathrm{~s}^{-1}\right)$ is the crystal growth rate, $\gamma$ is the interface tension crystal/solution $\left(\mathrm{J} \mathrm{m}^{-2}\right)$ and $\beta / \alpha(-)$ is the maximal ratio between $\beta$-lactose and $\alpha$-lactose. Standardised values are unitless. 

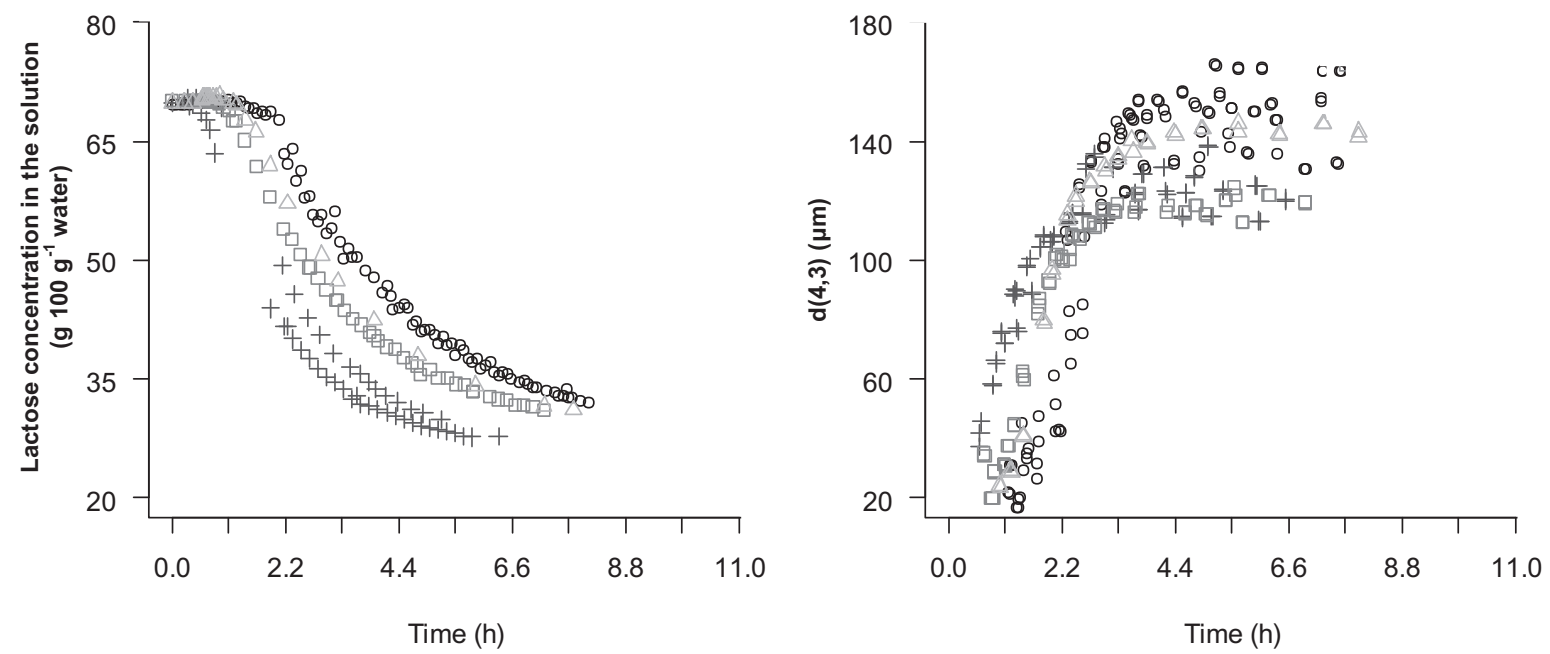

Fig. 5. Comparison of experimental kinetics of main paragons of each cluster and blank. Main paragons are individuals closest to the centre of the class. Panel a, plot of the corresponding desupersaturation experimental curves ( $\mathrm{g} 100 \mathrm{~g}^{-1}$ water concentration); panel b, plot of the corresponding $\mathrm{d}(4,3)(\mu \mathrm{m})$ experimental curves: $\bigcirc$, blank $($ solution 0$) ;+$, cluster 1 (solution7); $\square$, cluster 2 (solution 9); $\Delta$, cluster 3 (solution 3 ).

demonstrated that lactates and phosphates as well as a pH higher than 6 may accelerate lactose crystallisation. Moreover the accelerator effect of phosphates on crystallisation was hindered in the presence of calcium. Citing Modler and Lefkovitch (1986), Smart concluded that whey concentrates should be crystallised at the highest $\mathrm{pH}$ possible. Our study confirms these conclusions. Indeed, we observed that lactates and citrates were clearly separated from the other additives in terms of their crystallisation kinetics. Moreover, our results concerning calcium chloride were similar to those of the blank (solution 0 ), also confirming his results as he did not report any significant effect in the presence of calcium chloride.

\subsubsection{Cluster 2}

Cluster 2 contained all the experiments involving whey proteins. This cluster displayed low values for crystal growth kinetics. Comparison of the desupersaturation of the main paragon of this class and the blank shows clearly that, despite inhibition of crystal growth, lactose solutions with added whey proteins and related products have faster overall kinetics than lactose solutions without any additive, due to the more rapid nucleation rates (higher $J_{i}$ ) of the members of class 2 . These results confirm the previous work of Mimouni et al. (2005), which studied the crystallisation of lactose in the presence of proteins using a similar protocol, and showed that the addition of whey proteins did not affect the global kinetics, but did hinder crystal growth.

\subsubsection{Cluster 3}

Cluster 3 contained all the solutions that had neither rapid global kinetics nor low interface tension between crystal and solution. It was the largest cluster and it can also be viewed as a 'blank' cluster. In fact, while performing the same PCA with the blank as an active individual, the blank was the paragon of this cluster. Thus solutions present in this cluster were not very different from the reference.

\section{Conclusion}

This study presents a new approach to modelling of lactose crystallisation in dairy solutions. Through a systematic assay of different kinds of model solutions it confirmed previous research published on this topic by several authors. A new model describing lactose crystallisation was developed. It takes into account the different phenomena occurring during lactose crystallisation (nucleation, crystal growth, mutarotation) by a moment population balance method. This method works in a single step, and is assessed by a nonlinear least squares method, giving very reliable values for each parameter. This model was applied to the experimental results of crystallisations performed at a constant lactose/water ratio, with addition of varying amounts of organic and mineral constituents commonly found in whey. Our study provides new understanding by analysing more closely the specificity of the influence of the constituents on crystallisation through a model adjusting the crystallisation constants in one single step. Moreover it shows that lactate and citrate have an accelerating effect, in particular on crystal growth.

\section{Acknowledgements}

This study was part of a research project supported by Lactalis Ingredients (Bourgbarré, France), Herbignac Cheese Ingredients (Herbignac, France) and GEA-Process Engineering France (St Quentin en Yvelines, France). The authors are very grateful for their financial support and the many fruitful discussions. The authors want to thank also Florence Rousseau for her precious help during the experiments.

\section{References}

De Wit, J. N. (2001). Lecturer's handbook on whey and whey products (1st ed.). Brussels, Belgium: European Whey Products Association.

FIL-IDF. (2011). The world dairy situation 2011. Bulletin of the International Dairy Federation 451. Brussels, Belgium: International Dairy Federation.

Fox, J. (2005). The R Commander: a basic statistics graphical user interface to $\mathrm{R}$. Journal of Statistical Software, 14, 1-42.

Gernigon, G., Piot, M., Beaucher, E., Jeantet, R., \& Schuck, P. (2009). Physicochemical characterization of mozzarella cheese wheys and stretchwaters in comparison with several other sweet wheys. Journal of Dairy Science, 92, 5371-5377.

Haase, G., \& Nickerson, T. A. (1966). Kinetic reactions of alpha and beta lactose. ii. crystallization. Journal of Dairy Science, 49, 757-761.

Hartel, R. (2001). Crystallization in foods (1st ed.). Gaithersburg, MD, USA: Aspen Publishers.

Hartel, R., \& Shastry, A. (1991). Sugar crystallization in food products. Critical Reviews in Food Science and Nutrition, 30, 49-112. 
Husson, F., Josse, J., Le, S., \& Mazet, J. (2010). FactoMineR: Factor analysis and data mining with $R$. $R$ package version 1.14. http://CRAN.R-project.org/package=FactoMineR.

Husson, F., Josse, J., \& Pagès, J. (2010). Principal component methods - Hierarchical clustering - Partitional clustering: Why would we need to choose for visualizing data?. Technical report-Agrocampus. Available at: http://factominer.free.fr/ docs/HCPC_husson_josse.pdf.

Jolliffe, I. T. (2002). Principal component analysis. New York, NY, USA: Springer Verlag.

Mc Leod, J., Paterson, A. H. J., Jones, J. R., \& Bronlund, J. E. (2011). Primary nucleation of alpha-lactose monohydrate: the effect of supersaturation and temperature. International Dairy Journal, 21, 455-461.

Mersmann, A. (1995). Crystallization technology handbook (1st ed.). New York, NY, USA: Marcel Dekker, Inc.

Mimouni, A., Schuck, P., \& Bouhallab, S. (2005). Kinetics of lactose crystallization and crystal size as monitored by refractometry and laser light scattering: effect of proteins. Lait, 85, 253-260.

Mimouni, A., Schuck, P., \& Bouhallab, S. (2009). Isothermal batch crystallization of alpha-lactose: a kinetic model combining mutarotation, nucleation and growth steps. International Dairy Journal, 19, 129-136.

Modler, H. W., \& Lefkovitch, H. P. (1986). Influence of pH, casein, and whey-protein denaturation on the composition, crystal size, and yield of lactose from condensed whey. Journal of Dairy Science, 69, 684-697.

Morgan, F., Mollé, D., Henry, G., Vénien, A., Léonil, J., Peltre, G., et al. (1999). Glycation of bovine $\beta$-lactoglobulin: effect on the protein structure. International Journal on Food Science and Technology, 34, 429-435.
Nickerson, T. A., \& Moore, E. E. (1974). Factors influencing lactose crystallization. Journal of Dairy Science, 57, 1315-1319.

R Development Core Team. (2010). R: A language and environment for statistical computing. Vienna, Austria: R Foundation for Statistical Computing, ISBN 3900051-07-0, URL: http://www.R-project.org/.

Smart, J. B. (1988). Effect of whey components on the rate of crystallization and solubility of $\alpha$-lactose monohydrate. New Zealand Journal of Dairy Science and Technology, 23, 275-289.

Smithers, G. W. (2008). Whey and whey proteins - from 'gutter-to-gold'. International Dairy Journal, 18, 695-704.

Twieg, W. C., \& Nickerson, T. A. (1968). Kinetics of lactose crystallization. Journal of Dairy Science, 51, 1720-1724.

Visser, R. A. (1980). A natural crystal growth retarder in lactose. Netherlands Milk and Dairy Journal, 34, 255-275.

Visser, R. A. (1982). Growth of non-ionic lactose at various temperatures and supersaturations. Netherlands Milk and Dairy Journal, 36, 167-193.

Visser, R. A. (1984). Experiments for tracing growth retarders in lactose. Netherlands Milk and Dairy Journal, 38, 107-133.

Visser, R. A. (1988). Crystal growth retarding of alpha-lactose hydrate by sugar phosphates - a continued study. Netherlands Milk and Dairy Journal, 42, 449-468.

Wong, S. Y., Bund, R. K., Connelly, R. K., \& Hartel, R. W. (2010). Modeling the crystallization kinetic rates of lactose via artificial neural network. Crystal Growth and Design, 10, 2620-2628. 